\title{
„DLA JEDI CZAS NASTAŁ TAKŻE, BY JEŚĆ”. SCENY UCZTY W SADZE GWIEZDNE WOJNY
}

Dawid BARBARZAK

\section{ABSTRACT}

\section{"FOR THE JEDI IT IS TIME TO EAT AS WELL". EATING SCENES IN STAR WARS SAGA}

Feast scenes from the main Star Wars episodes play an important role the creation of the plot and characters. In the paper I divide them into three types. In the first part I discuss the scenes in which a feast or a meal is a pretext for the dialogues revealing the characters' past (the conversation between Luke and his uncle) or predict their future (little Anakin and Qui-Gon during the dinner; Anakin and Padmé's conversation predicting their fall). In the second part I present eating scenes through the authors create or underline the characteristic features of the protagonists (comism of Jar Jar Binks and Chewbacca; Jabba's gluttony; dehumanization of the black characters by the fact that they lack any contact with food) or build their social status (Rey's scavenger meal; feasts at tha palaces of Jabba and Amidala; Jedi master's ascetic meal on Dagobah; clones' canteen). To analyse the scenes I use theories developed by food anthropologists (Mary Douglas, Claude Levi-Strauss, and Katarzyna Łeńska-Bąk) and make references to classical mythology and the Bible. In the last part I raise questions about consumer's the identity of the character who eats juxtaposing devouring and eating scenes (why are Eworks considered humanoids whereas Wampa and Rancor are considered monsters since they all eat human flesh?). 


\section{WSTĘP}

Saga Gwiezdne wojny nie należy z pewnością do filmów szczególnie kojarzących się z kuchnią. W artykule The 50 Best Food on Film Moments of All Time, opublikowanym przez nowojorskie czasopismo związane z NYC Food Film Festival, znajdziemy sceny z filmów tak pozornie mało „kulinarnych”, jak Ojciec chrzestny czy Zakochany kundel, jednak ani jednej sceny z gwiezdnej sagi . Można się zastanawiać, z czego wynika ta właściwość. Możliwe, że twórcy poczynili na tyle duży wysiłek, kreując zupełnie nowe uniwersum, pełne odmiennych światów, ras, statków kosmicznych, wierzeń i obyczajów, że kwestie kulinariów pozostały na drugim planie. Innym wytłumaczeniem może być specyfika gatunku pełnego akcji, która nie sprzyja scenom odpoczynku, koniecznego przecież do ucztowania. Według antropolog Mary Douglas „Posiłki wymagają stołu, porządku siedzenia, ograniczenia ruchu i innych zajęć. Nie można robić na drutach podczas posiłku”’. Gdy toczą się wojny, również galaktyczne, zwykle nie ma więc czasu na jedzenie. Dlatego też Napoleon, jak trafnie wskazuje autorka, pozostając w stanie wojny z Austriakami, „w dniu bitwy nie jadł nic aż do jej zakończenia”, dopiero potem podano mu słynnego kurczaka $\mathrm{z}$ rakami ${ }^{3}$.

Sceny posilków mogą pełnić w filmach różne funkcje. Niektórzy twórcy osadzają całą akcję dzieła wokół stołu, inni czynią te sceny czysto epizodycznymi, niemającymi większego wpływu na główny wątek fabularny. Ponieważ akt jedzenia ma wymiar głęboko społeczny ${ }^{4}$, więc spotkania wokół stołu mogą wyrażać, bądź stanowić pretekst do wyrażania, głębi relacji międzyludzkich, nie tylko tych pozytywnych. Wspólny posiłek spożywany przez bohaterów stanowi doskonałe tło toczonych przy stole dialogów, podczas których ujawnia się ich tożsamość. W filmie Ferzana Öspetka Mine Vaganti. O miłości i makaronach (2010) syn informuje swoją tradycjonalistyczną rodzinę, że jest gejem, a drugi z synów, że nie zamierza przejąć rodzinnego interesu ojca. Kilkoma słowami wypowiedzianymi przy stole zupełnie odwracają przypisywane im przez krewnych role społeczne. Paolo Genovese w swoim Dobrze się kłamie w miłym towarzystwie (2016) owo „odkrywanie prawdy o sobie” podczas kolacji czyni wręcz głównym wątkiem filmu. Bohater Dobrego roku (2006) Ridleya Scotta łączy lata swojego dzieciństwa ze smakiem wina, jakim częstował go wujek z Prowansji. Filmy o tematyce

S. Bruning, J. Rothman, C. Schonberger, M. Uyehara, The 50 Best Food-on-Film Moments of All Time [online], 8 października 2011 [dostęp: 14 stycznia 2017]. Dostępny w World Wide Web: https://www.timeout. com/newyork/restaurants/the-50- best-food- on-film- moments-of-all-time\#tab_panel_5.

M. Douglas, Odszyfrowanie positku [w:] Ukryte znaczenia. Wybrane szkice antropologiczne, thum. E. Klekot, Kęty 2007, s. 335-361, tu: s. 342.

Tamże, s. 345.

L. Kolmer, Wprowadzenie. Rytuaty zjednoczenia [w:] Jedzenie. Rytuaty i magia, red. F.T. Gottwald, L. Kolmer, tłum. E. Ptaszyńska-Sadowska, Warszawa 2009, s. 11-17, tu: s. 11-12. 
kulinarnej dotykają czasem kwestii społecznych czy zawodowych, prezentując chociażby historie kucharzy. Przykładem jest Szef Jona Favreau (2014), w którym tytułowy szef kuchni zwolniony z luksusowej restauracji zakłada własny interes i wyrusza w trasę food truckiem. Przedsięwzięcie staje się pretekstem do nawiązania więzi z synem, a także poznania sekretów z przeszłości żony. Z kolei w produkcji Wielkie otwarcie Stanleya Tucciego i Campbella Scotta (1996) między dwoma włoskimi imigrantami z USA wybucha konflikt na tle chęci dogodzenia oczekiwaniom klientów z jednej strony, a zachowaniem tradycyjnych włoskich receptur, z drugiej.

Nawet te nieliczne wymienione przykłady historii filmowych pokazują, że ucztowanie i kulinaria pełnią najprzeróżniejsze funkcje i mogą stanowić punkt wyjścia do rozważań natury filozoficznej czy społecznej, a jednocześnie zachęcają do naukowego zglębienia tych problemów. Waldemar Frąc, wychodząc z perspektywy antropologiczno-filozoficznej, wyróżnił trzy filmowe formuły odnoszenia się bohatera do spożywania pokarmów: negację (nieograniczona niczym hedonistyczna konsumpcja prowadząca do cierpienia, bólu i negacji samego życia), destrukcję (jedzenie jako zgubne lekarstwo na lęki egzystencjalne, lączące wysoki poziomu estetyki przy niskim poziomie moralności) i afirmację (uczta wyrażająca jedność ducha i ciała, akceptację własnej osoby i empatię wobec towarzyszy stołu $)^{5}$. Podczas analizy badacz wskazał na konkretne produkcje filmowe, podbudowując swe rozważania filozofią Fryderyka Nietzschego, Maxa Schelera czy Zygmunta Baumana. W toku tych rozważań zastosuję inną typologię filmowych scen uczty, skoncentrowaną na ich roli w kreowaniu fabuly filmowej. Podczas analizy poszczególnych postaci sięgnę jednak częściowo po zaproponowane wyżej teorie.

Na temat jedzenia w świecie Gwiezdnych wojen ukazały się liczne materiały internetowe. Są to w większości teksty bądź nagrania wideo o charakterze popularnym, niejednokrotnie humorystycznym. Na uwagę zasługują niewielkie artykuły autorstwa Dana Zehra i Adama Braya, zamieszczone na oficjalnej stronie serii, poświęcone wybranym scenom jedzenia w starej i nowej trylogii oraz w serialach animowanych ${ }^{6}$. Nie są to jednak teksty w pełni naukowe: nie poddają one scen głębszej analizie czy typologii, ograniczając się do ich wyliczenia. Dotychczasowy brak podobnego studium

W. Frąc, Odżywianie ciała - odżywianie ducha? Filmowe wizualizacje [w:] Pokarmy i jedzenie w kulturze. Tabu, dieta, symbol, red. K. Łeńska-Bąk, Opole 2007, s. 313-319.

D. Zehr, Studying Skywalkers: Thanksgiving in the Original Trilogy [online], 26 listopada 2014 [dostęp: 30 maja 2017]. Dostępny w World Wide Web: http://www.starwars.com/news/studying-skywalkers-thanksgiving-inthe-original-trilogy; tenże, Studying Skywalkers: Thanksgiving in the Prequel Trilogy [online], 28 stycznia 2015 [dostęp: 30 maja 2017]. Dostępny w World Wide Web: http://www.starwars.com/news/studying-skywalkers-thanksgivingin-the-prequel-trilogy; A. Bray, 10 Great Food Scenes in Star Wars Rebels and Star Wars The Clone Wars [online], 2 września 2015 [dostęp: 30 maja 2017]. Dostępny w World Wide Web: http://www.starwars.com/news/10-greatfood-scenes-in-star-wars-rebels-and-star-wars-the-clone-wars. 
skłonił mnie do podjęcia badań umożliwiających odpowiedź na pytanie, jakie role odgrywają sceny uczty w głównych siedmiu epizodach sagi Gwiezdne wojny. W tym celu za konieczne uznałem stworzenie pewnej typologii scen według pełnionych przez nie funkcji z perspektywy budowy narracji filmowej oraz kreacji postaci. Niektóre sceny wplywają na kształtowanie warstwy fabularnej, zwłaszcza przez nawiązujące się podczas uczty dialogi. Gdy akcja zwalnia, bohaterowie podczas posiłków odkrywają prawdę o swojej przeszłości lub zapowiadają (werbalnie bądź behawioralnie samym zachowaniem przy stole) swoje przyszłe losy. Sceny te nazwałem na potrzeby artykułu „ucztami proroczymi” i poświęcę im pierwszy podrozdział. Drugi dotyczyć będzie tych scen, które przez akt jedzenia podkreślają bądź wprost kreują charakter postaci (czarne charaktery, postacie komiczne, zdrajcy, postawy gościnności i empatii). Jakość posiłków, sposób ich spożywania wyrażają także status społeczny i majątkowy bohaterów (zamożni-ubodzy, władcy-podwładni, świeccy-duchowni, kobiety-mężczyźni). Tym zagadnieniom poświęcam trzeci podrozdział. Oczywiście niektóre sceny sytuować się będą w kilku proponowanych kategoriach, niemniej jednak podział wydaje się uzasadniony. Podejmuję także temat antagonizmu między jedzeniem a pożeraniem, czyli próbę rozgraniczenia potworów i ras humanoidalnych. W pracy korzystam z teorii wypracowanych przez antropologów jedzenia , a język niektórych symboli staram się odczytać w duchu tradycji judeochrześcijańskiej i mitologii klasycznej.

Należy podkreślić, że celem artykułu nie jest analiza "galaktycznego menu”. Pojawiające się w Gwiezdnych wojnach potrawy czy napoje nie są szerzej komentowane w samych filmach. Stanowią raczej zagadkę dla fanów serii oraz pożywkę dla autorów wyrosłych na gruncie sagi seriali, gier, książek czy komiksów. Dopiero oni nadają tym pobocznym wątkom filmowym pełną specyfikę. Dlatego też uchwycenie „galaktycznego menu" wiązałoby się z analizą zakulisowych intencji twórców, a zwłaszcza wspomnianej sfery „expanded universe”, powstającej na bazie głównej sagi, lecz jednocześnie już poza nią ${ }^{8} \mathrm{Z}$ tego powodu pominę także temat przepisów kulinarnych wyrosłych na popularności serii (na mleko Banthy, korzeniuszkę Yody i inne ${ }^{9}$ ) oraz promocyjnych

M. Douglas, dz. cyt.; C. Lévi-Strauss, Trójkąt kulinarny [w:] Antropologia ciała. Zagadnienia i wybór tekstów, oprac. A. Chałupnik, J. Jaworska, J. Kowalska-Leader, J. Kurz, M. Szpakowska, red. M. Szpakowska, Warszawa 2008, s. 57-63; K. Łeńska-Bąk, O pokarmach, smakach i utraconych znaczeniach. Historia kultury sub specie culinaria, Opole 2010.

Brak informacji o produktach spożywczych w filmach daje autorom serii pole do kreatywności w obrębie tzw. expanded universe, którego efektem są książki, gry i komiksy, fanom zaś pozwala formułować definicje zawarte na takich portalach, jak Wookieepedia, gdzie znaleźć można również dokładne opisy kulinariów: http://starwars.wikia. com/wiki/Category:Food_by_culture) [dostęp: 30 maja 2017]. Łącząc fakty z oficjalnych epizodów oraz expanded universe, fani sagi stają się w ten sposób współautorami uniwersum.

Przepisy te można znaleźć na oficjalnej stronie serii [online], [dostęp: 30 maja 2017]. Dostępny w World Wide Web: http://www.starwars.com/news/category/recipes/page/2. 
produktów spożywczych sygnowanych logotypem Star Wars. Zagadnienia te zasługują na odrębne studium socjologiczne lub antropologiczne.

\section{UCZTY PROROCZE}

Pierwszy rodzaj scen, jakiemu się przyjrzymy, to te, w których uczta staje się pretekstem do dialogu między bohaterami. W rozmowach przy stole odkrywają oni przed sobą (i widzem) tajemnice swych przeszłych i przyszłych losów. Gesty i słowa wyrażane przy stole kryją w sobie relacje społeczne panujące wśród jedzących posiłek. Jak pisze w swoim artykule Dan Zehr: „Saga jest pełna licznych przykładów jedzenia, budujących społeczność i wspólnotę; jedzenie to ważne narzędzie literackie, wyrażające, że oto dzieje się coś istotnego, a Gwiezdne wojny dostarczają na to wielu przykładów"

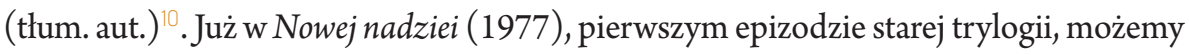
obserwować scenę z kuchni i jadalni na pustynnej farmie Larsów. Adoptowany przez nich chłopiec, od dziecka pracujący na farmie i marzący o zostaniu pilotem, przerywa swe codzienne obowiązki w porze obiadu. Wspólne posiłki z wujostwem oznaczają $\mathrm{w}$ istocie dzielenie losu farmera, poddanie się władzy wuja. Można przypuszczać, że podobny scenariusz powtarzał się w życiu Luke’a codziennie. Obiad w Nowej nadziei doprowadza jednak do konfliktu, zapowiadającego przełom w życiu bohatera. Rozmowa przy stole dotyczy zaszyfrowanej w zakupionym niedawno robocie wiadomości do niejakiego Obi-Wana Kenobiego. Luke, wykazując altruizm, proponuje przekazać wiadomość adresatowi. Wuj jednak, znając zawiłą przeszłość ojca Luke’a oraz ObiWana, kłamliwie utrzymuje, że obaj nie żyją:

LUKE: A jeśli ten Obi-Wan będzie go [robota - przyp. aut.] szukał?

WUJ OWEN: Nie będzie. Zdaje się, że nie żyje. Zginął w tym samym czasie, co twój ojciec.

LUKE: Znał mojego ojca?

WUJ OWEN: Miałeś o tym zapomnieć.

Wuj zleca młodzieńcowi czyszczenie pamięci robota, pragnąc w istocie, by zapomniał o przeszłości, a jednocześnie nie odkrył prawdy o swoim przeznaczeniu. Luke, chcący wstąpić do szkoły pilotów, łamie wujowską wizję wspólnej pracy przy żniwach i spokojnym bytowaniu na farmie (co wyraża wspólny posiłek):

LUKE: Złożę podanie do akademii jeszcze w tym roku.

WUJ OWEN: Jesteś mi potrzebny. Jeszcze tylko jeden sezon.

LUKE: Rok temu mówiłeś to samo!

10 D. Zehr, Studying Skywalkers... Prequel, dz. cyt. 
Narastająca w Luke'u frustracja sprawia, że zostawia on niedokończony posiłek i opuszcza jadalnię. Wymowność sceny podkreśla fakt wyjścia z domu i spojrzenia na horyzont, zerwanie z bezpieczeństwem i swojskością (symbolizowaną przez stół) na rzecz wypełnienia swojego losu. Odmowa uczestniczenia w uczcie ma swoje antropologiczne podstawy, których przykłady znajdujemy w historii ${ }^{11}$. Może wyrażać się jako bunt o charakterze politycznym czy ideologicznym, którego skrajną formą jest strajk głodowy. Gdy Luke opuszcza jadalnię, siedząca dotąd w milczeniu ciocia Beru wyraża zrozumienie dla potrzeb przybranego dziecka: „Luke nie będzie farmerem. Jest zbyt podobny do ojca”. Dopiero spotkanie z Kenobim, który wręcza młodzieńcowi świetlny miecz ojca, będzie dla Luke’a inicjacją na wzór mitycznego Tezeusza, który u progu swej dorosłości odnaleźć miał miecz i sandały Ajgeusa ${ }^{12}$.

Postawa wuja Owena, z jednej strony egoistyczna (szukanie pomocnika na farmie), z drugiej empatyczna (chęć chronienia Luke’a i troska o jego bezpieczeństwo), wypada tym niekorzystniej w świetle sceny z Ataku klonów (2002). Z prequela wynika bowiem, że młodzi Larsowie, dokładnie w tej samej jadalni, gościli przed laty rodziców Luke’a. Zauważmy, że tak jak Luke opuszcza posiłek, symbolicznie wychodząc na poszukiwania ojca, podobnie jego ojciec Anakin odmówił wówczas gościny u Larsów, by szukać zaginionej matki. O ile dla syna oznacza to wstąpienie na drogę Jedi, o tyle dla ojca był to początek upadku, podyktowany fatalnym przywiązaniem do przeszłości. Kolejne przykłady wykażą, że wszystkie niemal sceny rodzinnych posiłków w sadze niosą z sobą konflikt stron, $\mathrm{w}$ którym troska krewnych o bezpieczeństwo bohatera ściera się z jego własną wolą wypełnienia swojego losu. Jednocześnie jest to spór między obojętnością opiekuna a drzemiącym w bohaterze altruizmem.

Podczas uczty w Mrocznym widmie (1999) zapowiedziany zostaje los małego Anakina, który wraz z matką służy jako niewolnik handlarzowi złomu Watto. Chłopiec oferuje rozbitym na Tatooine przybyszom pomoc. Na czas burzy piaskowej zaprasza ich do domu na kolację, podczas której proponuje wzięcie udziału w wyścigu ścigaczy, by wygraną przeznaczyć na części do statku rozbitków. Podczas rozmowy przy kolacji altruistycznej postawie Anakina przeciwstawiony zostaje głos rozsądku jego matki:

Lothar Kolmer podaje tutaj przykład Henryka IV, który po spotkaniu w Canossie w obecności papieża nie tknął żadnej potrawy, ugruntowując atmosferę konfliktu, L. Kolmer, dz. cyt., s. 15. Także podczas rytualnego potlaczu Indian północnego Pacyfiku odejście od stołu wiązało się z poczuciem nienależytego uhonorowania, dla gospodarza zaś z utratą możliwości potwierdzenia swych przywilejów rodzinnych, J.L. Rousellot, Potlacz - uroczysty positek Indian pótnocno-zachodniego wybrzeża [w:] Jedzenie. Rytualy i magia, red. F.T. Gottwald, L. Kolmer, thum. E. Ptaszyńska-Sadowska, Warszawa 2009, s. 189-196, tu: s. 194.

Plutarch, The Life of Theseus, 3.1 [w: ] Paralell Lives, Vol. I, London 1914. 
MATKA: Umieram ze strachu, kiedy Watto cię do tego zmusza.

ANAKIN: Ale ja to uwielbiam mamo! Nagroda jest wysoka, mogliby kupić części [...]. Mówiłaś, że największym problemem kosmosu jest to, że sobie nie pomagamy. $[\ldots]$

MATKA: On może wam pomóc, to mu było sądzone.

Znów mamy do czynienia z konfliktem na osi „obojętność-biernośćbezpieczeństwo” (matka) i „altruizm-działanie-ryzyko (syn). W ostatnim zdaniu matki pobrzmiewa jednak pogodzenie się z losem syna-wybrańca, podobnie jak u cioci Beru w Nowej nadziei. Podczas tej samej kolacji zapowiedziane zostają losy Anakina jako Jedi. Już przy pierwszym spotkaniu z rycerzem Qui-Gon Jinnem Anakin częstuje go na straganie owocem, który Jedi chowa pod płaszcz, odsłaniając przed chłopcem miecz świetlny (to zapowiedź przyszłych losów chłopca, znak wynagrodzenia jego gościnności) ${ }^{13}$. Wątek ten powraca przy stole:

ANAKIN: Jesteś rycerzem Jedi? [... ] Widziałem twój miecz. Tylko Jedi noszą tę broń.

QUI-GON: Może zabiłem któregoś Jedi i zabrałem mu miecz.

ANAKIN: Nie sądzę. Nikt nie może zabić Jedi.

QUI-GON: Chciałbym, żeby tak było... [...]

ANAKIN: Śniło mi się raz, że zostałem Jedi. Wróciłem tu i uwolniłem niewolników ${ }^{14}$.

Rozmowa wieszczy więc nie tylko przyszłość Anakina jako Jedi, lecz także rychły zgon Qui-Gona, który wyraził tutaj świadomość swej śmiertelności. Z kolei naiwna wiara Anakina we wszechmoc Jedi zapowiada w luźny sposób jego fatalne dążenia do nieśmiertelności z Zemsty Sithów.

Również wątek zakazanej miłości Anakina i Padmé zostaje pogłębiony podczas ich rozmów przy stole. W jednej z wyciętych scen Ataku klonów (2002) kobieta zaprasza zakochanego w niej Anakina do rodzinnego domu na planecie Naboo ${ }^{15}$. Domownicy, zwłaszcza rodzice, niepokoją się znów o bezpieczeństwo służącej Republice córki, na którą przeprowadzono nieudany zamach:

13 Postawę afirmacji pełnego altruizmu opisał W. Frąc na przykładzie filmu Uczta Babette (1986), w której bohaterka oddaje wszystko, co ma (wygraną na loterii), by zorganizować kolację dla swoich gospodarzy. Anakin, ubogi niewolnik, prezentuje postawę podobną: zaprasza potrzebujących na ucztę, po czym bezinteresownie daruje im swój dobytek (wygraną w wyścigu), W. Frąc, dz. cyt., s. 318.

Anakin prezentuje archetyp Wybrańca. Wątek wyzwolenia jeńców pojawia się między innymi w żydowskich proroctwach mesjańskich (Iz 42,6-7).

Anakin \& Padme Visit The Naberrie Home [online], 17 lipca 2017 [dostęp: 25 marca 2018]. Dostępny w World Wide Web: https://www.youtube.com/watch?v=K0xqWD1xz5Y. 
PADMÉ: To Jedi wysłany przez Senat, by mnie chronić.

MATKA: Ochroniarz? Dlaczego nie powiedziałaś nam, że to tak poważne?

PADMÉ: Nie jestem w niebezpieczeństwie, mamo.

OJCIEC: Jest?

ANAKIN: Tak, obawiam się, że jest.

Rodzinny stól, jako symbol ostoi bezpieczeństwa, znów staje się miejscem do dyskusji właśnie o bezpieczeństwie krewnych. Anakin jest w domu osobą obcą i rodzina próbuje odczytać jego tożsamość, a także wybadać uczucia łączące go z Padmé:

SIOSTRA [przy stole]: Wiesz, że jesteś pierwszym chłopakiem, którego Padmé przyprowadziła do domu?

PADMÉ: To nie jest mój chłopak. To przyjaciel, znamy się od lat $[\ldots]$

Po posiłku rozmowa przenosi się do kuchni i toczy bez skrępowania. Kobiety plotkują, obserwując „zza kulis” Anakina spacerującego za oknem:

MATKA [ $w$ kuchni]: Dlaczego nam o nim nie powiedziałaś?

PADMÉ: A o czym tu mówić? To tylko chłopiec.

SIOSTRA: Chłopiec? Widziałaś, w jaki sposób na ciebie patrzy? To pewne, że czuje coś do ciebie.

Kuchnia w domu rodzinnym Padmé odgrywa zatem rolę sfery prywatnej w odróżnieniu od publicznej jadalni, gdzie przyjmuje się gości i ostrożnie bada ich tożsamość. Domysły krewnych co do relacji łączącej Anakina i Padmé oczywiście są słuszne, biorąc pod uwagę końcową scenę Ataku klonów potajemnego ślubu zakochanych. Jest to więc „uczta prorocza”, jednak o tak łatwym do przewidzenia skutku (zwłaszcza dla widza znającego starą trylogię), że rezygnacja twórców z tej sceny wydaje się zrozumiała. Zadziwia z kolei zupełny brak sprzeciwu rodziny, świadomej przecież, że Jedi nie wchodzą w związki partnerskie, pozostając w stanie celibatu. Inna scena Ataku klonów ukazuje, jak Anakin przekonał samą Padmé, że kodeks Jedi wcale nie jest przeszkodą na drodze do ich związku. Rozmowa toczy się w lokalu podczas lekkiego positku:

PADMÉ: Wolno ci kochać? Myślałam, że to zabronione dla Jedi.

ANAKIN: Zabronione jest przywiązywanie się. Współczucie, które możemy rozumieć jako bezwarunkową miłość, jest centralną rzeczą w życiu Jedi. Można powiedzieć, że zachęca się nas do miłości.

W rozmowie tej Anakin odwraca znaczenie miłości bezwarunkowej (którą po grecku nazwalibyśmy agape), myląc ją z romantyczną wizją miłości pełnej namiętnego i fatalnego przywiązania (eros). W innej scenie w pałacu na Naboo Anakin - pozornie niewinną zabawą przy stole - bezpośrednio lamie kodeks Jedi. 
Podczas deseru przyciąga on leżącą na talerzu Padmé gruszkę, wprawia ją w lot, po czym posyła odkrojony kawałek wprost do ust ukochanej. Popisując się przed partnerką, nadużywa Mocy, którą Jedi powinni wykorzystywać w służbie Republice. Świadczy o tym komentarz Anakina, jakby głos sumienia: „Gdyby mistrz Obi-Wan przyłapał mnie na tym, strasznie by zrzędził”. Sama gruszka jawi się tu może jako symbol zakazanego owocu, nieszczęścia będącego następstwem nieposłuszeństwa wobec kodeksu ${ }^{16}$. Symboliczne zerwanie zakazanego owocu, podobnie jak w Księdze Rodzaju (Rdz 2,16-17), staje się przyczyną klęski. Prowadzi on do śmierci kobiety, osierocenia jej potomstwa oraz, pośrednio, do upadku Republiki. Zauważmy, że Palpatine (Imperator) przyjmuje tutaj funkcję kusiciela: podważa zasady Jedi (odpowiednik przestrogi Stwórcy), obiecując Anakinowi nieśmiertelność, jakby nieosiągalny owoc Drzewa Życia (Rdz 3,22).

Ważne dla kształtowania głównego wątku fabularnego sceny rozgrywają się nie tylko przy stołach rodzinnych, lecz także w lokalach publicznych. Zwłaszcza knajpy portowe to miejsca, gdzie zawierają się transakcje i umowy, mające wplyw na przebieg dalszych wydarzeń. To właśnie w kantynie Mos Eisley krzyżują się losy Luke’a i szmuglera Hana Solo, od którego chłopak przy kieliszku wynajmuje transport, by wkrótce wstąpić w szeregi Rebelii i odnaleźć swą siostrę. Wiele lat później podobna scena pojawia się w zamku Maz Kanaty, gdzie Rey i Finn, przy stoliku zastawionym drinkami i owocami, zastanawiają się nad dołączeniem do Ruchu Oporu. To tutaj Rey otrzymuje miecz Skywalkera i wyrusza na poszukiwania mistrza. Bohaterowie siadają więc do stolika, by rozważyć swoje losy, a decyzje przy nim powzięte diametralnie wpływają na ich tożsamość. Te i wcześniejsze obrazy „uczt proroczych” stanowią dowód na to, że w trakcie toczonych przy stole rozmów, do których posiłek bądź napój jest pretekstem, odkrywa się przed bohaterami ich przeszłość, wieszczą przyszłe losy, bądź zapadają zwyczajne ustalenia dotyczące nadchodzących wydarzeń.

16 W tradycji europejskiej utrwaliło się wyobrażenie rajskiego owocu jako jabłek, może przez łaciński homonim malum (oznaczający jabłko oraz zło). W niektórych interpretacjach mogły to być inne owoce. Objawienia mistyczne Anny Katarzyny Emmerich z XVIII w. sugerują gruszki. Zob. Z. Ram, The Life of Anne Catherine Emmerich, London 1874, s. 58. Podobnie św. Augustyn (Conf. 2.4.8-9) wskazuje na skradzione w dzieciństwie gruszki, jako początek swych młodzieńczych grzechów, zob. Augustyn, Wyznania, edycja komputerowa, s. 36-37, [online], [dostęp: 9 kwietnia 2018] http://iwanicki.edu.pl/wp-content/uploads/2016/11/augustyn_wyznania.pdf. 


\section{KREOWANIE CHARAKTERÓW POSTACI}

Inny rodzaj scen uczty w Gwiezdnych wojnach, który można wyróżnić, nie ma szczególnego wpływu na bieg akcji, ale kreuje charakter postaci bądź jej status społeczny. W scenach tych istotny jest nie tyle towarzyszący posiłkom dialog, ile sam charakter jedzenia i sposób, w jaki dana postać konsumuje. Wśród scen tego typu znajdziemy kilka mających podkreślić role bohaterów komicznych. W Powrocie Jedi (1983), podczas misji Rebelii na księżycu Endor, Chewbacca znajduje zawieszony na drzewie kawałek mięsa. Skuszony, wciąga przyjaciół w zastawione sidła, sprawiając, że wszyscy lądują w zawieszonej na gałęzi sieci. Twórcy wyeksponowali komiczne cechy Wookieego: niezdrową ciekawość, łapczywość i nieopanowanie, co najlepiej wyraża komentarz tkwiącego w pułapce Hana Solo: „Dobra robota, Chewie. Zawsze myślisz tylko o swoim żołądku”. Pomijając zabawny wygląd i język postaci, komizmu dodaje mu związane z jedzeniem imię (chew, ang. 'żuć). Inną postacią, której cechy komiczne przydano przez sceny jedzenia, jest Jar Jar Binks. Podczas kolacji u Skywalkerów w Mrocznym widmie wykazuje on zupełny brak manier przy stole, wciągając kolejne porcje jedzenia swym wydłużonym językiem. Faux pas jest tym większe, że rozmowa toczy się na poważny temat losu niewolników na Tatooine. W innej scenie Jar Jar Binks kradnie ze straganu suszące się żaby, wylewając niechcący zupę na jedzącego obok Sebulbę. Brak odpowiednich manier podczas filmowych bankietów może mieć potencjał humorystyczny (przykład Pretty Woman Garry'ego Marshalla z $1990 \mathrm{roku}^{17}$ ), ale także stanowić o zróżnicowaniu społecznym bohaterów (przypomnijmy sobie postać Jacka, który w Titanicu Jamesa Camerona z roku 1997, zaproszony na salony, zdezorientowany zasiada przed zestawem sztućców i odmawia kawioru). Również Jar Jar Binks reprezentuje niską klasę społeczną, jest przecież banitą.

Sceny uczt podkreślają nieraz charakter pozytywnych postaci, uwypuklając zwłaszcza ich gościnność. Cechę tę u małego Anakina i jego matki widzieliśmy już podczas omawiania „uczt proroczych” w Mrocznym widmie (zaproszony Qui-Gon: „Twój syn zaoferował nam schronienie”). Wiele lat później zaproszona przez chłopca Padmé poda dorosłemu już Anakinowi kubek niebieskiego mleka, a także zaprosi go na rodzinny obiad. Przygotowują go i podają jej matka i siostra, z którymi po posiłku Padmé sprząta, przebywając w kuchni. Oto, jak prezentuje się gościnność rodziców w scenie powitania:

MATKA PADMÉ: Trafiliście idealnie na obiad. Mam nadzieję, że jesteś głodny, Anakinie.

\footnotetext{
$17 \quad$ L. Kolmer, dz. cyt., s. 14.
} 
ANAKIN: Trochę.

PADMÉ: Umieramy z głodu!

OJCIEC: Jesteście więc we właściwym miejscu, o właściwej porze.

Otwarty dom i zastawiony stół symbolizują empatię i gościnność bohaterów. Zauważmy, że w lakonicznej odpowiedzi Anakina (gościa) kryje się kurtuazyjność, a może skrępowanie nowym środowiskiem ${ }^{18}$. Gościnność i poczęstunek pomagają przełamać lody między dotąd obcymi sobie postaciami, jak widzimy w domu Padmé. Jeszcze wymowniejsza jest scena spotkania księżniczki Lei z tubylcem po tym, gdy gubi się ona w lesie na księżycu Endor (Powrót Jedi). Ponieważ jedno nie zna języka drugiego, napotkany Ewok pozostaje nieufny. Dopiero gdy bohaterka oferuje mu wyjętą z ekwipunku przekąskę (i na znak, że nie jest otruta, sama próbuje jej wcześniej), tubylec ostrożnie siada obok niej i zjada ciastko. Waldemar Frąc, omawiając afirmatywną formułę jedzenia w filmie Gabriela Axela Uczta Babette (1987), dochodzi do podobnych wniosków: „Babette, katoliczka w gronie ascetycznych protestantów, nieznająca języka, zaczyna komunikować się ze swymi pracodawczyniami przede wszystkim dzięki językowi kulinarnemu”' ${ }^{\text {" }}$.

Niejednokrotnie jednak pod pozorem poczęstunku czy nawet wspólnej uczty kryć się może podstęp i zdrada. Klasycznymi wzorcami ze świata mitologii i Biblii są tutaj Judyta (zabójstwo Holofernesa po uczcie), Judasz podczas Ostatniej Wieczerzy („Lecz oto ręka mojego zdrajcy jest ze Mną na stole”, Łk 22,21) czy Tantal wystawiający bogów na próbę. Wprowadzenie podobnych scen pozwala podkreślić przewrotny bądź zdradziecki charakter postaci. W początkowych scenach Mrocznego widma Qui-Gon Jinn i Obi-Wan Kenobi zostają pozornie ciepło przyjęci na statku Federacji Handlowej. „Wasza wizyta to dla nas wielki zaszczyt, ambasadorowie. Rozgośćcie się, mój pan zaraz do was dołączy”, wita ich robot, podając napoje do stolika. Dopiero później wkraczają roboty bojowe mające zabić gości. Podobnie w Imperium kontratakuje (1980) Lando Calrissian prowadzi przyjaciół do jadalni („Może wpadniecie na małą przekąskę? Jesteście zaproszeni!”). Przy stole jednak czekają już szturmowcy i Darth Vader („Będziemy zaszczyceni, jeśli do nas dołączycie”), a Han i Leia zostają pojmani. Innym razem to Han Solo podstępnie zabija nasłanego na siebie łowcę głów Greedo przy barowym stoliku. Stół między nimi pozostaje pusty (brak kieliszka odzwierciedla brak porozumienia), a właściwa relacja zachodzi paradoksalnie pod stołem (odbezpieczenie pistoletu), w miejscu niewidocznym dla przechytrzonego rozmówcy.

18 Już średniowieczne traktaty dotyczące etykiety dworskiej zalecały umiarkowanie, gdyż łapczywość i obżarstwo nie przystawały do statusu dobrze urodzonych. Wymijająca odpowiedź Anakina wyraża jego dobre wychowanie i kurtuazję wobec „teściów”, por. F. Quellier, Łakomstwo. Historia grzechu głównego, tłum. B. Spieralska, Warszawa 2013, s. 33-39.

19 W. Frąc, dz. cyt., s. 318. 
Postacie czarnych charakterów kreowane są także za pomocą przedstawienia sposobu, w jaki konsumują. Powrót Jedi wprowadza postać gangstera Jabby, w którego pałacu na Tatooine panuje atmosfera wiecznego bankietu. Gra muzyka na żywo, tańczą skąpo ubrane kobiety, a rozsiadly na swym tronie Jabba pali fajkę wodną, wyciągając raz po raz pływające w zalewie żaby. Postać łączy w sobie cechy włoskiego mafiosa (działalność kryminalna, ściganie wrogów), rzymskiego imperatora i tureckiego baszy. Poza opisanym już otoczeniem, twórcy podkreślili czarny charakter postaci jego manierami. Jabba nie używa sztućców, je rękoma, co w kulturze zachodniej ma długą tradycję napiętnowania ${ }^{20}$. Jabba właściwie nie tyle obżera się, ile delektuje wykwintnymi (acz obrzydliwymi) potrawami. Anthelme Brillat-Savarin, który rozróżnił żarłoków i smakoszów, zaliczyłby Hutta w poczet tych ostatnich ${ }^{21}$. I choć jego tusza wynika raczej z rasy niż nieumiarkowania, wygląd postaci budzi u widza jednoznaczne skojarzenia z obżarstwem. Nie bez powodu ucztowaniu towarzyszą piękne kobiety: już od średniowiecza grzech łakomstwa (łac. gula) stawiano często obok rozwiązłości (łac. luxuria), a pierwszy prowadzić miał do drugiego ${ }^{22}$. Posiłkom Jabby, niczym rzymskim cesarzom, towarzyszą krwawe rozrywki, dostarczane przez Rancora, potwora pożerającego wrogów w lochu pod salą. Ich krzyki i cierpienie nie przeszkadzają gangsterowi w zajadaniu kolejnych żab, w czym przypomina widzów kinowych sięgających po popcorn. Również wyścig ścigaczy w Mrocznym widmie obserwuje on z loży (jak w rzymskim cyrku), a zawody otwiera splunięciem odgryzioną głową żaby w gong. Pożywienie Jabby nie budzi pozytywnych skojarzeń. Przysłowie „Jesteś tym, co jesz” w przypadku Hutta nabiera wielce komicznego, dosłownego znaczenia: sam bowiem przypomina skrzyżowanie żaby i węża (na co zresztą wskazuje etymologia imienia Jabba the Hutt, zapożyczona od czeskich słów žába oraz had). W filmowej parodii Kosmiczne jaja (reż. Mel Brooks, 1987) Jabba został przedstawiony jako Pizza the Hut, z ciałem składającym się z pizzy. Obrzydzenie budzą również Gamorreanie, świniopodobni strażnicy pałacowi, oraz majordom Jabby Bib Fortuna z mackami na głowie (dopiero w później powstałych epizodach rasę Twi'Leków reprezentowały także pozytywne postacie). Żaby, gady czy świnie,

20 Już nowożytni podróżni europejscy, odwiedzający Imperium Osmańskie, z niechęcią spoglądali na tamtejszy zwyczaj jedzenia rękoma: „Pod koniec wieku XVII podróżni traktowali brak noży i widelców jako dowód na to, że mieszkańcy Wschodu byli, jak ujął to Thomas Smith, «nie obeznani z wykwintem i lepszym jedzeniem»”, zob. B. Jezernik, Dzika Europa. Bałkany w oczach zachodnich podróżników, tłum. P. Oczko, Kraków 2007, s. 44.

A. Brillat-Savarin, Fizjologia smaku albo medytacje o gastronomii doskonatej, oprac. W. Zawadzki, tłum. J. Guze, Warszawa 2015, s. 94-95.

F. Quellier, dz. cyt., s. 17. Zauważmy, że gdyby Jabbie towarzyszyły żeńskie przedstawicielki jego rasy, zamiast efektu haremu i wrażenia rozwiązłości osiągnięto by efekt groteskowy. Podobnie został przedstawiony w Mrocznym widmie dug Sebulba, rywal Anakina. Choć używa łyżki, łączy w sobie obrzydliwy wygląd, agresję oraz wyuzdanie (przed wyścigiem podów masują go humanoidalne przedstawicielki rasy Twi'Lek, tej samej rasy co tancerki i majordom Jabby). 
nieważne czy ukryte w pożywieniu postaci czy w samym ich wyglądzie, wywołują w widzu wyrosłym w kulturze judeochrześcijańskiej pejoratywne skojarzenia. Prawo żydowskie zabraniało jedzenia stworzeń pozbawionych płetw i łusek $(K p ł 11,9)$. Świnia zaś uchodziła za zwierzę nieczyste, a choć często konsumowana w kulturze zachodniej, semantycznie pozostaje nosicielką „odium wielorakiego skalania”, synonimem brudu, obżarstwa, opilstwa i wielu innych przywar, w tym seksualnych ${ }^{23}$.

Próby kreacji bohaterów za pomocą scen uczty wpisują się we wspomnianą typologię Waldemara Frąca, w której wyróżnia on formułę negacji, destrukcji i afirmacji w odniesieniu do spożywanych przez bohaterów posiłków. Dwie z tych formuł postaram się omówić tutaj na przykładzie Jabby i Padmé. Formuła destrukcji opiera się na zanegowaniu klasycznej Wielkiej Triady (piękno, prawda, dobro). Jak wskazuje autor, znajduje ona odzwierciedlenie w filmie Kucharz, złodziej, jego żona i jej kochanek (1989) Petera Greenawaya. Pięknu wyszukanych potraw i luksusowej restauracji zostają przeciwstawione zachodzące w niej akty niemoralności ${ }^{24}$. Nietzsche podkreślał, że jedyny sens leży w estetyce, a człowiek sam musi stać się dziełem sztuki. W filmie Greenawaya owym dziełem sztuki kulinarnej staje się upieczony mężczyzna, były kochanek żony głównego bohatera. W podobny sposób prezentuje się Jabba i jego bankiet. Wysoka estetyka otoczenia stanowi jedynie przykrywkę wobec czyhającego w gospodarzu zła, które najpełniej wyraża kryjący się w podziemiach salonu potwór. Rządy i uczty Jabby opierają się na przemocy (łańcuchy na szyjach tancerek) symbolicznie pożerającej przeciwników - czy to z pomocą Rancora, czy mieszkającego na pustyni Sarlacca. Jak pisze Lothar Kolmer: „Za najcięższe przestępstwo uważano zamordowanie gościa $\mathrm{w}$ trakcie proszonej biesiady [...] polityczne skrytobójstwa spotykały niewinnych gości, a odpowiedzią na nie były stosowne akty zemsty, na przykład używanie czaszek krewnych jako puchary" ${ }^{25}$. Ustawienie zamrożonego Hana Solo w pałacu Jabby, jako zemsta za dług i zabicie nasłanego Greedo, w pełni odpowiada temu modelowi.

Odmienną formułę odniesień do posiłków, mimo równie silnej władzy i wysokiego statusu majątkowego, prezentuje postać Padmé. Jako władczyni zostaje ona świadomie wykreowana na głęboko empatyczną i skromną. Choć w swym pałacu nawet gruszkę spożywa sztućcami, wiele lat wcześniej nie gardzi skromną kolacją w chacie niewolników

M. Douglas, dz. cyt., s. 359-360.

W. Frąc, dz. cyt., s. 317. Podobną filozofię podejścia do uczty znaleźć możemy w antycznej uczcie Trymalchiona, zekranizowanej przez Federica Felliniego w Satyriconie (1969). Hedonistyczny nihilizm Trymalchiona pobrzmiewa w jego słowach: „Biada nam nędznym, niczym nie jest człowiek cały. Wszyscy będziemy tacy, gdy nas Orkus schłonie. Przeto też żyjmy, czas nam teraz się weselić!” (Petroniusz, Satyryki, tłum. L. Staff, cyt. za: C. Hartz, My chcemy orgii! Jak świętowali starożytni Rzymianie, tłum. E. Ziegler-Brodnicka, Warszawa 2017, s. 138).

L. Kolmer, dz. cyt., s. 16. 
na Tatooine ${ }^{26}$. Zauważmy, że w jej domu rodzinnym posiłków nie serwuje służba, choć przeszkodą nie są tu kwestie finansowe. W typologii Waldemara Frąca stosunek Padmé do posiłków sytuowałby się w formule afirmatywnej, którą już omawialiśmy. Jabba nie jest jedynym przykładem kształtowania czarnego charakteru dzięki scenom posiłków. W zupełnie inny sposób twórcy sagi wykreowali oficerów Imperium, szturmowców oraz Sithów. Zauważmy, że próżno szukać sceny, w której ktokolwiek $\mathrm{z}$ nich konsumowałby posiłek. Zabieg ten z pewnością ma na celu dehumanizację postaci. Spożywanie posiłku wskazuje na głęboko ludzką potrzebę, pewne fizjologiczne ograniczenie, których zaspokojenie wymaga przyjęcia postawy pokory wobec konieczności „bycia nakarmionym” (jak dziecko). Czarne charaktery nie mają jednak czasu na odpoczynek, wciąż pochłonięte wypełnianiem rozkazów i ściganiem wrogów. Odwróceniem tej konwencji jest postać Wargorra w kampanii czekolady Wedel. Ta inspirowana Darthem Vaderem postać chętnie zajada się czekoladą i okazuje sympatię wobec dzieci, co wywołuje komiczny efekt ${ }^{27}$. Ostatnia scena Zemsty Sithów przedstawia podniesienie się Dartha Vadera ze stołu operacyjnego. Dan Zehr dopatruje się w tej scenie symboliki wznoszenia się ponad znak ludzkiej wspólnoty (stól), podyktowanego chęcią nieograniczonej władzy nad śmiercią ${ }^{28}$. Skłonny jestem zakwestionować tę teorię, brak bowiem podstaw do stawiania analogii między stołem operacyjnym i kuchennym. Z całą pewnością uznać należy jednak, że Vader, chcąc przekroczyć ludzką śmiertelność, stracił swe człowieczeństwo, a z nim prawdopodobnie możliwość spożywania normalnych posiłków.

\section{PŁEĆ, STATUS SPOŁECZNY I RASA BOHATERÓW}

Społeczność galaktyczną w świecie Gwiezdnych wojen podzielić można na stany i warstwy społeczne, co w zależności od statusu znajduje odzwierciedlenie również w scenach posiłków. Kolację na farmie Larsów możemy uznać za posiłek rodzinny, podobnie jak ten w domu Padmé na Naboo. Warto zauważyć, że przygotowywaniem i podawaniem pożywienia $\mathrm{w}$ roli gospodyń najczęściej zajmuje się płeć żeńska ${ }^{29} . \mathrm{Za}$ przygotowanie obiadu na Tatooine odpowiada ciocia Beru. Wycięta scena z Nowej nadziei prezentuje ją przy pracy, wrzucającą warzywa do garnka i nalewającą niebieskie

26 Pogarda szlachty wobec pożywienia chłopów uwypuklała ich status, będąc formą klasyfikacji społecznej, co podkreślał Pierre Bourdieu, por. Stoly pańskie i chłopskie. Od wyznaczania różnic społecznych do mody na "swojskość" [w: ] K. Łeńska-Bąk, dz. cyt., s. 102.

27 N. Gawrońska, Gwiezdne wojny i reklamy [online], 13 października 2015 [dostęp: 25 marca 2018]. Dostępny w World Wide Web: https://nowymarketing.pl/a/7227,gwiezdne-wojny-i-reklamy.

D. Zehr, Studying Skywalkers... Prequel, dz. cyt.

29 Zob. Jedzenie i pteć. O budowaniu tożsamości, strategiach ciała i kanonach piękna [w:] K. Łeńska-Bąk, dz. cyt., s. 135 . 
mleko $^{30}$. Rodzina Larsów wydaje się prezentować model patriarchalny. Mężczyźni na znak gospodyni („Luke! Obiad gotowy!”) odchodzą od pracy. Przy stole głos w sporze zabierają wyłącznie mężczyźni, podczas gdy Beru, nie chcąc może podważać autorytetu męża, zachowuje milczenie ${ }^{31}$. Wiele lat wcześniej Padmé podaje zmęczonemu Anakinowi kubek niebieskiego mleka (odwrotnej płciowo sceny nie znajdziemy), a także zaprasza go na rodzinny obiad. Zasiadanie do wspólnego posiłku, zwłaszcza ciepłego, oznacza najbliższy rodzaj więzi społecznej: „Napoje są dla obcych, znajomych, dla zatrudnionych fachowców i rodziny. Posiłki są dla rodziny, bliskich przyjaciół

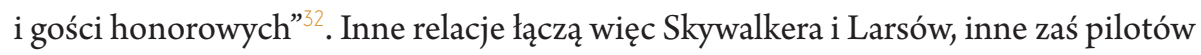
i szmuglerów opróżniających kieliszki w kantynie Mos Eisley.

Galaktyczne knajpy portowe pełniące funkcję węzłów komunikacyjnych są miejscem spotkań przybyszów z różnych części galaktyki. Przy kieliszku prowadzi się interesy, mające znaczny wpływ na bieg akcji: to właśnie tutaj Luke i Obi-Wan dobijają targu na transport. Alkohol, lejący się w Mos Eisley, doprowadza do scen rodem z saloonów na Dzikim Zachodzie. Przy jazzowej muzyce uprawia się gry hazardowe, wyrównuje dawne rachunki (strzelanina między Hanem a łowcą głów), a miejscowe opryszki skłonne są do awantury pod byle pretekstem. Zauważmy, że Obi-Wan, nim użył sily w obronie Luke’a zaczepionego przez dwóch takich awanturników, proponuje im kolejkę przy barze. Kantyny to prawdziwie męski świat, gdzie nie ma miejsca na ciepłe posiłki, symbol zaufania i wartości rodzinnych. Han Solo, kreowany na galaktycznego kowboja, nigdy w serii nie został przedstawiony podczas jedzenia. Prawdziwy mężczyzna, niczym James Bond, prosi tylko o kieliszek (po czym zupełnie trzeźwy prowadzi samochód czy statek kosmiczny). Mary Douglas zaobserwowała, że piciu zwykle towarzyszą mniej zażyłe więzy społeczne: „wspólne spożywanie napojów (zauważmy płynność głównego elementu, brak ustrukturyzowania, małe, nieprzyklejające się do palców pożywienie w formie stałej) wyraża, jeszcze jaśniej dzięki kontrastowi, nietrwałość i oderwanie właściwe prostszym i mniej zażyłym więzom społecznym"33. Gdy w Ataku klonów Obi-Wan udaje się do starego przyjaciela Dextera Jettstera, prowadzącego bar szybkiej obsługi „Dex’s Diner” na Coruscant, męska rozmowa, choć serdeczna, dotyczy interesów i toczy się przy kubeczku „Jawa juice”.

Oprócz różnic płciowych uwypuklonych w scenach uczt wskazać można także na różnice w statusie majątkowym czy klasowym bohaterów. Posiłek w domu Larsów może uchodzić za przykład pożywienia klasy średniej, przeciętnych rolników żyjących

30 A New Hope (1977) Deleted Scene: Aunt Beru Prepares Blue Milk [online], 19 października 2015 [dostęp: 25 marca 2018]. Dostępny w World Wide Web: https://www.youtube.com/watch?v=4ysHxlpywUY.

K. Łeńska-Bąk, dz. cyt., s. 135.

M. Douglas, dz. cyt., s. 342 .

Tamże, s. 345 . 
na rubieżach galaktyki. Już jednak wystawne uczty Jabby czy wykwintne desery w pałacu senator Amidali (gdzie owoce podaje służba, a gruszkę je się nożem i widelcem) wyraźnie wskazują na zamożność gospodarzy.

Na drugim końcu tej drabiny społecznej znajdują się z pewnością osoby pokroju Rey, zbieraczki złomu. W Przebudzeniu Mocy zamiast pensji otrzymuje ona od szefa dzienne racje żywnościowe. Jest to może próba wskazania przez twórców na problem wyzysku pracowniczego w krajach rozwijających się ${ }^{34}$. Chleb błyskawiczny, gotowy po zalaniu wodą niczym zupka chińska, zaśniedziałe naczynia, uschnięte kwiaty w wazonie, skrobanie kolejnych dni na ścianie przydaje posiłkowi Rey atmosfery niemal więziennej. Dziewczyna je w pośpiechu (wyraz głodu), w samotności (wyraz sieroctwa) i posługuje się palcami (wyraz niskiego statusu). Brak manier, widoczny w nieużywaniu sztućców i wylizywaniu talerza, budzi u widza raczej współczucie niż obrzydzenie (jak w przypadku Jabby) czy rozbawienie (Jar-Jar Binks). Krótka scena wspólnego posiłku klonów w stołówce na planecie Kamino niesie z sobą jeszcze inne znaczenia. Żołnierze są pozbawieni wolnej woli („Są całkowicie posłuszni, wykonują każdy rozkaz bez pytania”). Dlatego też przedstawiono ich w całkowitej uniformizacji: jedzą o tej samej porze, przy wspólnym stole, z identycznych białych tac i naczyń. To wyraz wojskowej dyscypliny i relacji władzy, budzący jednakże pozytywne skojarzenia (zauważmy, że szturmowcy, choć poddani uniformizacji, w ogóle nie konsumują). Niewiele jedzą też żołnierze Rebelii: podczas wypraw spożywają proste racje żywnościowe, przypominające batoniki zbożowe (używa ich Luke na Dagobah w Imperium kontratakuje oraz Leia na Endorze w Powrocie Jedi).

W Gwiezdnych wojnach można również pokusić się o społeczne rozróżnienie świeckich i duchownych. Ten drugi stan reprezentować mogą Jedi, stanowiący zakon rycerski, w którym obowiązywały pewne normy żywieniowe. Choć są wojownikami, bywają przedstawiani podczas konsumpcji, co nadaje im pozytywne cechy ludzkie. Jedną ze słynniejszych scen, stanowiącą tytuł niniejszego rysu, jest ta, w której mistrz Yoda przygotowuje „korzeniuszkę” na bagiennej planecie Dagobah, dokąd przed laty udał się na wygnanie. Posiłek mistrza Jedi jest prosty i wegetariański (co przywodzić może konotacje buddyjskie), a jednocześnie bardzo skromny (ascetyzm) ${ }^{35}$. Yoda

34 Problemu tego dotyka reportaż Martina Caparrósa, zob. tenże, Głód, tłum. M. Szafrańska-Brandt, Kraków 2016. Zastanawiające jest, że Gwiezdne wojny, w odróżnieniu od sfery technologicznej przywodzącej wizje futurystyczne, w gastronomii nie przejawiają takich skłonności (o tym zagadnieniu zob. W.J. Belasco, Meals to Come: A History of the Future of Food, Berkeley 2006).

Podobnie ascetyczną kuchnię prezentuje stary Luke Skywalker w Ostatnim Jedi (2017). Żyjąc w ukryciu na Ahch-To, spożywa on proste posiłki, bazujące na produktach miejscowych. Styl jego życia przypomina bohatera Przypadków Robinsona Crusoe Daniela Defoe. Luke łowi ryby morskie oraz pije mleko (zielone), dojone wprost z ssaków zwanych Thala-sirens. Jego uczennicy, Rey, wiodącej dotąd życie na nizinach społecznych, nie razi ten niewyrafinowany styl żywienia, nadto wydaje się ona pełna podziwu dla sprawności polującego starca. 
jednak, w przeciwieństwie do swojego ucznia Luke’a, podkreśla wartość i konieczność spożywania posiłków. Młody adept, któremu brakuje cierpliwości, nie chce tracić czasu na posiłek. Zaaferowany chęcią odnalezienia Yody, nie domyśla się, że oto mistrz stoi przed nim:

YODA: Gotuję korzeniuszkę!

LUKE: To na pewno pyszne, ale dlaczego nie możemy już teraz poszukać Yody? YODA: Cierpliwości! Dla Jedi czas nastał także, by jeść.

Z perspektywy Yody posiłek wydaje się symbolem cierpliwości, zastanowienia, wyciszenia, cech kontrastujących z pośpiechem i chęcią działania jego ucznia. Po śmierci Obi-Wana Luke jest pozbawiony mistrza. Jego stan można porównać do kondycji apostołów po śmierci Chrystusa. Niemożność dostrzeżenia Yody przez Luke’a odnajdujemy w analogicznej historii apostołów zmierzających do Emaus, kiedy także dopiero posiłek z Mistrzem pozwala Go rozpoznać (Łk 13,24-31). „Dla Jedi czas nastał także, by jeść” to jakby parafraza biblijnej zasady „wszystko ma swój czas” (Koh 3,1) oraz „że człowiek je i pije [... ] to wszystko dar Boży” (Koh 3,13). Nowotestamentowa scena posłania apostołów następuje dopiero po wspólnym śniadaniu nad brzegiem jeziora. Najpierw padają słowa „Chodźcie, posilcie się”, a dopiero później skierowane do Szymona Piotra „Pójdź za mną” ( J 21,1-15). Podobnie Luke, nim przystąpi do treningu i ciężkiej próby spotkania z ojcem, zaproszony jest do zjedzenia korzeniuszki.

Saga George’a Lucasa przedstawia nie tylko ludzi, ale również inne rasy zamieszkujące galaktykę, a ponadto zwierzęta i potwory. Rodzi to pewną kontrowersję, trudno bowiem wytyczyć granicę między scenami jedzenia i pożerania. Poza wszelkimi wątpliwościami są sceny połknięcia robota R2-D2 przez bagiennego potwora z Dagobah czy pochłonięcia statku kosmicznego Hana Solo przez giganta Exogortha zamieszkującego asteroidy (Imperium kontratakuje). Podobną scenę widzimy w Mrocznym widmie, gdy podwodną lódź bohaterów próbuje połknąć ryba. Przywodzi to na myśl pewne motywy baśniowe czy mityczne (jak Lewiatan czy wielka ryba z Księgi Jonasza). Są to jednak sceny dodające dramatyzmu akcji i próżno szukać w nich większych alegorii. Bardziej zastanawiający jest status takich stworzeń, jak Wampa (inspirowany yeti) czy wspomniany Rancor z pałacu Jabby. Wykreowane na postacie jednoznacznie negatywne (zagrażające pożarciem głównym bohaterom), wydają się kwalifikować do kategorii potworów. Co jednak miałoby stanowić o odmówieniu im statusu jednej z galaktycznych ras? Co odróżnia Wampę od Wookieego, skoro cechuje ich podobny wygląd, a jedno i drugie żywi się surowym mięsem ${ }^{36}$ ? Czy to, że

36 Jedzenie surowego mięsa, a więc nieoddzielanie krwi w kulturze żydowskiej wiązało się z nieczystością (Kpł 17,10; Pwt 12,23-27). Mary Douglas (dz. cyt., s. 255-257) dowodzi, że unikanie krwi u Żydów miało charakter tożsamościowy i związane było z niechęcią do mieszania się z obcymi narodami, które nie przestrzegały czystości 
Wookiee nie poluje na ludzi i rozumie ich język ${ }^{37}$ ? Co w takim razie odróżnia Wampę od plemienia Ewoków, które polowały na ludzi, a zostały przedstawione jako jedna $\mathrm{z}$ inteligentnych, przyjaznych ras? Można wskazywać na poziom ucywilizowania: wcześniej wszak opiekały na ogniu swe ofiary (acz żywcem, co z kolei stawia Wampę w bardziej humanitarnym świetle ${ }^{38}$. Może hełmy pokonanych szturmowców, służące jako trofea po bitwie o Endor, to dowód na kanibalizm wojenny Ewoków? Ciężko zresztą uznać Ewoki za kanibali, gdyż zjadali oni osobników obcych - ze swej perspektywy - ras. Na te i podobne kwestie trudno znaleźć logiczną odpowiedź, gdyż samym twórcom zabrakło z pewnością konsekwencji w spójnym powiązaniu całości ${ }^{39}$. Scena opiekania Hana Solo przez Ewoki wywołać miała raczej efekt komiczny aniżeli poważne rozważania na temat kulinarnego tabu. Podobną zagadkę stanowi scena w najnowszej części sagi, Ostatni Jedi (2017), w której Chewbacca opieka nad ogniem porgi, rodzaj nadmorskich ptaków z planety Ahch-To. Trzymając w ręku opieczonego ptaka i mając na sobie spojrzenie jego żywych kompanów, Chewbacca - jakby męczony wyrzutami sumienia - nie jest w stanie skosztować mięsa i płoszy gapiów. Wydaje się, że autorzy Star Wars wpletli tutaj dyskurs ekologiczny czy wegański. Chewie zaprzyjaźnia się później z porgami, które wiją sobie gniazdo na jego statku „Sokole Millennium”. Dzięki tej scenie, choć wciąż mającej chyba budzić humor, twórcy nadali scenom kulinarnym $\mathrm{w}$ trzeciej trylogii wyraz społecznego zaangażowania ${ }^{40}$.

rytualnej. Tworzono w ten sposób opozycję Żydzi-inni. W uniwersum Gwiezdnych wojen możemy pokusić się o dychotomię rasy myślące-potwory, jednak wytyczenie linii między nimi nie jest łatwe.

Wookieepedia, hasło Wookiee [online], [dostęp: 25 marca 2018]. Dostępne w World Wide Web: http:// starwars.wikia.com/wiki/Wookiee. Z serialu Clone Wars dowiadujemy się, że wielki moff Lozen Tolruck polował na Wookieech (objaw rasistowskiej polityki Imperium, przywodzącej na myśl problematykę naukowego rasizmu i eksterminacji). Wookiee są społeczeństwem lowieckim planety Kashyyyk. Z powieści Świt Rebelii A.C. Crispin dowiadujemy się o ich zwyczaju rytualnego polowania, w którym młody Wookiee musi upolować swej wybrance zwierzę o nazwie trakkrrrn, po czym poczęstować ją żeberkami, zob. Star Wars Wikia [online], [dostęp: 25 marca 2018]. Dostępne w World Wide Web: http://starwars.wikia.com/wiki/Barbecued_trakkrrrn_ribs.

38 Claude Lévi-Strauss zauważa, że pieczenie pokarmów na ogniu jest bliższe natury i właściwe dla żywiołu męskiego, gotowanie zaś (które wymaga stworzenia garnka) ma bardziej kulturowy i kobiecy charakter, por. tenże, Trójkąt kulinarny [w: Antropologia ciała. Zagadnienia i wybór tekstów, oprac. A. Chałupnik, J. Jaworska, J. KowalskaLeader, J. Kurz, M. Szpakowska, red. M. Szpakowska, Warszawa 2008, s. 57-63. Pieczenie ma również konotacje piekielne i wyraża śmierć wroga, związaną z egzokanibalizmem.

O dość przypadkowym charakterze tworzenia postaci Ewoków mówią sami twórcy. Początkowo planowano, by to plemię Wookieech stało się pogromcami Imperium w bitwie o Endor, jednak postać obeznanego z techniką Chewiego nie pasowała do konceptu „prymitywnego” plemienia. Nazwa „Ewok” powstała przez odwrócenie sylab wook-ie oraz jako skojarzenie z plemieniem Indian Ameryki Północnej Miwok. Por. J. Miller, Where There's Life, There's Lawsuits: Not Altogether Serious Ruminations on Law and Life, Toronto 2003, s. 146.

40 Po premierze filmu ukazała się ilustrowana książeczka dla dzieci Chewie and the Porgs (K. Shinick, F. Hsieh, Disney-Lucasfilm Press 2017), promująca wartość przyjaźni bez względu na wygląd czy pochodzenie (hasło promujące: „Friends come in all shapes and sizes”). Jednocześnie w Internecie pojawily się liczne żarty z Chewiego wegetarianina. W jednym z parodystycznych komiksów Rey pyta Chewiego „Dlaczego nie spróbowaleś pieczonych porgów? Zostałeś ich przyjacielem?”, na co ten odpowiada: „Nie, teraz jestem muzulmaninem: żadnych porgów!” (gra słów: no porgs brzmi podobnie do no porks, tj. „żadnej wieprzowiny”). 


\section{WN1OSK1 KOŃCOWE}

Przytoczone wyżej przykłady wskazują na to, że we wszystkich epizodach filmowych Gwiezdnych wojen występują sceny spożywania posiłków. Przedstawiona typologia dowodzi, że niektóre z tych scen służą za pretekst do prowadzenia istotnych dialogów, rzutujących na losy głównych bohaterów. Inne sceny kulinarne mają za zadanie kreować lub też podkreślać różnorodne charaktery postaci, wywołując komizm, sympatię czy antypatię ze strony widza. Jak starałem się wykazać, jakość posiłku, sposób jego serwowania i konsumpcji są wyznacznikami statusu społecznego bohaterów. Zaproponowana typologia pozwala lepiej skategoryzować sceny uczty w sadze Star Wars, choć nie jest najpewniej jedyną formą przeprowadzenia podziału. Wskazane kategorie są zresztą płynne, gdyż wiele scen można zaliczyć zarówno do „uczt proroczych”, jak i tych kreujących charaktery postaci czy wskazujących na ich status społeczny. Kolacja na Tatooine w Mrocznym widmie jest tego doskonałym przykładem. Zapowiada ona przyszłe losy Anakina, a jednocześnie podkreśla cechy bohaterów (gościnność chłopca i jego matki, skromność Padmé, brak manier Jar Jar Binksa i jego niskie pochodzenie społeczne). I w końcu, niektóre ze scen prowadzą do pytań granicznych o tożsamość bohaterów: kwestie rasowe i problem rozdzielenia ras humanoidalnych od zwierząt i potworów. Wszystkie przykłady świadczą o tym, że obecność scen uczty w sadze Gwiezdne wojny, choć nie jest dominująca, odgrywa bardzo istotne i złożone role w kształtowaniu warstwy fabularnej. 


\section{BIBLIOGRAFIA}

\section{FILMY}

Gwiezdne wojny: Atak klonów, reż. G. Lucas, Lucasfilm, 20th Century Fox 2002.

Gwiezdne wojny: Imperium kontratakuje, reż. I. Kershner, Lucasfilm, 20th Century Fox 1980.

Gwiezdne wojny: Mroczne widmo, reż. G. Lucas, Lucasfilm, 20th Century Fox 1999. Gwiezdne wojny: Nowa nadzieja, reż. G. Lucas, Lucasfilm, 20th Century Fox 1977. Gwiezdne wojny: Powrót Jedi, reż. G. Lucas, Lucasfilm, 20th Century Fox 1983. Gwiezdne wojny: Przebudzenie Mocy, reż. J.J. Abrams, Lucasfilm, Walt Disney Pictures 2015.

Gwiezdne wojny: Zemsta Sithów, reż. G. Lucas, Lucasfilm, 20th Century Fox 2005.

Gwiezdne wojny: Ostatni Jedi, reż. R. Johnson, Lucasfilm, Walt Disney Pictures 2017.

Anakin \& Padme Visit The Naberrie Home [online], 17 lipca 2017 [dostęp: 25 marca 2018]. Dostępny w World Wide Web: https://www.youtube.com/ watch?v=K0xqWD1xz5Y.

A New Hope (1977) Deleted Scene: Aunt Beru Prepares Blue Milk [online], 19 października 2015 [dostęp: 25 marca 2018]. Dostępny w World Wide Web: https:// www.youtube.com/watch?v=4ysHxlpywUY.

\section{ŹRÓDŁA}

Augustyn, św., Wyznania, edycja komputerowa, s. 36-37, [online], [dostęp: 9 kwietnia 2018] http://iwanicki.edu.pl/wp-content/uploads/2016/11/augustyn_ wyznania.pdf.

Biblia Tysiąclecia [online], Poznań 2013 [dostęp: 30 maja 2017]. Dostępny w World Wide Web: http://www.biblia.deon.pl.

Plutarch, The Life of Theseus, 3.1 [w: ] Paralell Lives, Vol. I, London 1914.

\section{OPRACOWANIA}

Belasco W.J., Meals to Come: A History of the Future of Food, Berkeley 2006.

Brillat-Savarin A., Fizjologia smaku albo medytacje o gastronomii doskonatej, oprac. W. Zawadzki, tłum. J. Guze, Warszawa 2015.

Caparrós M., Głód, tłum. M. Szafrańska-Brandt, Kraków 2016.

Crispin A.C., Świt Rebelii, tłum. A. Syrzycki, Warszawa 2001.

Douglas M., Odszyfrowanie posiłków [w:] Ukryte znaczenia: wybrane szkice antropologiczne, tłum. E. Klekot, Kęty 2007, s. 335-361. 
Frąc W., Odżywianie ciała - odżywianie ducha? Filmowe wizualizacje [w:] Pokarmy i jedzenie w kulturze. Tabu, dieta, symbol, Opole 2007, s. 313-319.

Hartz C., My chcemy orgii! Jak świętowali starożytni Rzymianie, thum. E. ZieglerBrodnicka, Warszawa 2017.

Jezernik B., Dzika Europa. Bałkany w oczach zachodnich podróżników, tłum. P. Oczko, Kraków 2007.

Kolmer L., Wprowadzenie. Rytuaty zjednoczenia [w: Jedzenie. Rytuaty i magia, red. F.T. Gottwald, L. Kolmer, tłum. E. Ptaszyńska-Sadowska, Warszawa 2009, s. 11-17.

Lévi-Strauss C., Trójkąt kulinarny [w:] Antropologia ciała. Zagadnienia i wybór tekstów, oprac. A. Chałupnik, J. Jaworska, J. Kowalska-Leader, J. Kurz, M. Szpakowska, red. M. Szpakowska, Warszawa 2008, s. 57-63.

Łeńska-Bąk K., O pokarmach, smakach $i$ utraconych znaczeniach. Historia kultury sub specie culinaria, Opole 2010.

Miller J., Where There's Life, There's Lawsuits: Not Altogether Serious Ruminations on Law and Life, Toronto 2003.

Quellier F., Łakomstwo. Historia grzechu głównego, tłum. B. Spieralska, Warszawa 2013.

Ram H., The Life of Anne Catherine Emmerich, London 1874.

Rousellot J.L., Potlacz - uroczysty positek Indian pótnocno-zachodniego wybrzeża [w: Jedzenie. Rytuały i magia, red. F.T. Gottwald, L. Kolmer, tłum. E. PtaszyńskaSadowska, Warszawa 2009, s. 189-196.

Shinick K., Hsieh F., Chewie and the Porgs, Disney-Lucasfilm Press 2017.

\section{PUBLIKACJE DOSTĘPNE W INTERNECIE}

Bray A., 10 Great Food Scenes in Star Wars Rebels and Star Wars The Clone Wars [online], 2 września 2015 [dostęp: 30 maja 2017]. Dostępny w World Wide Web: http://www.starwars.com/news/10-great-food-scenes-in-star-wars-rebels-and-starwars-the-clone-wars.

Bruning S., Rothman J., Schonberger C., Uyehara M., The 50 Best Food-onFilm Moments of All Time [online], 8 października 2011 [dostęp: 14 stycznia 2017]. Dostępny w World Wide Web: https://www.timeout.com/newyork/restaurants/ the-50-best-food-on-film-moments-of-all-time\#tab_panel_5.

Gawrońska N., Gwiezdne wojny i reklamy [online], 13 października 2015 [dostęp: 25 marca 2018]. Dostępny w World Wide Web: https://nowymarketing. $\mathrm{pl} / \mathrm{a} / 7227$,gwiezdne-wojny-i-reklamy. 
Zehr D., Studying Skywalkers: Thanksgiving in the Original Trilogy [online], 26 listopada 2014 [dostęp: 30 maja 2017]. Dostępny w World Wide Web: http:// www.starwars.com/news/studying-skywalkers-thanksgiving-in-the-original-trilogy. Zehr D., Studying Skywalkers: Thanksgiving in the Prequel Trilogy [online], 28 stycznia 2015 [dostęp: 30 maja 2017]. Dostępny w World Wide Web: http:// www.starwars.com/news/studying-skywalkers-thanksgiving-in-the-prequel-trilogy. 